\title{
Identity is an Infinite Now: Being Instead of Becoming Gallina
}

\section{Lewis Borck \& Erik Simpson}

To cite this article: Lewis Borck \& Erik Simpson (2017) Identity is an Infinite Now: Being Instead of Becoming Gallina, KIVA, 83:4, 471-493

To link to this article: https://doi.org/10.1080/00231940.2017.1391155

$$
\text { 曲 Published online: } 22 \text { Nov } 2017 .
$$

Submit your article to this journal $[\pi$

Q View related articles $₫$

View Crossmark data $\nearrow$ 


\title{
Identity is an Infinite Now: Being Instead of Becoming Gallina
}

\author{
LEWIS BORCK' AND ERIK SIMPSON ${ }^{2}$ \\ ${ }^{1}$ Faculty of Archaeology, Leiden University, Leiden, Netherlands \\ ([l.s.borck@arch.leidenuniv.nl], corresponding author) \\ 2 Division of Conservation Archaeology, Salmon Ruins, Bloomfield, NM, \\ USA
}

\begin{abstract}
Archaeological research on the Gallina (AD 1100-1300) inhabitants of the region west of the Rio Chama and centered on the Llaves valley has focused on constructing a culture history and examining functional characteristics of artifacts and architecture. Limited research has attempted to understand who the residents of the Gallina heartland were. In this article, using new findings and historical contexts, we argue that the Gallina people had a complicated identity forged around resistance and a deep connection to their past. To better understand them we need to move past previous binary categories used to describe them and perceive them not as isolated or connected, aggressors or victims, traditionalists or innovators, but as an intersectional mix of these axes of identity.
\end{abstract}

La investigación arqueológica sobre los habitantes Gallina (1100-1300 d. C.) de la región oeste del Río Chama, focalizada en el valle de Llaves, se orientó en la construcción de una historia cultural y el análisis de las características funcionales de los artefactos y la arquitectura. De hecho, han sido escasas las investigaciones que han intentado entender quiénes eran los residentes del Gallina. En este artículo, utilizando nuevos hallazgos y contextos históricos, argumentamos que los grupos Gallina tuvieron una identidad compleja, forjada en torno a la resistencia y a una profunda conexión con su historia. Asimismo, para entenderlas necesitamos movernos más allá de las tradicionales categorías binarias usadas para interpretarlos y percibirlos como aislados o conectados, violentos o víctimas, tradicionalistas o inventores, y en cambio, como una mezcla que abarca todos estos ejes de identidad.

KEYWORDS Gallina, Social identity, Resistance, Power, Hierarchy, Egalitarianism, Pueblo, History 
Archaeologists have interpreted the inhabitants of the Gallina highlands as either a distinct people or an archaeological phase relating to the Upper San Juan culture area. An archaeological phase can have temporal and geographic relevance, but it does not necessarily reflect how the people who lived and dialogically constructed and maintained their cultural worlds either viewed or organized themselves (Trigger 2008:2II-3I3). As gross characterizations of cultures based on material traits, phases are often idealized as representing regional norms (e.g., Kidder I924). But in doing so, they often fail to adequately account for internal difference (although see McGregor I94I). This failure to recognize variation within phases and cultures leads to the creation of transitional areas (sensu Harry and Herr 2018) and other archaeological non-places (sensu Augé 1995; Borck 2017).

While it may be technically accurate to discuss the Gallina as a phase in the local Pueblo transitional sequence, it fails to fully capture the historicity, innovation, and agency the residents of the Gallina highlands displayed when they moved into the region at approximately $\mathrm{AD}$ I IO० (although see Bremer and Burns $20 \mathrm{I}_{3}$ for a re-evaluation of the beginning dates for Gallina). For this article, we will examine the Gallina region from an intersectional social identity perspective, that highlights diversity, incorporates contradiction, and acknowledges that the construction of the social self arises from multiple axes of social interaction (Combahee River Collective [1977]; Shannon and Rogue [2014]).

Social identity has often been incorporated into anthropology and archaeology as an avenue to reveal how individuals and groups distinguish themselves from others (Jenkins 2004:4). Materially, this is often expressed as highly visible markers of association (Carr I995; Clark 200I). As these markers change, they signal shifts in political and social relationships. These high visibility markers are more useful than domestic material assemblages (Steen 1999) for understanding purposeful signaling for identity affiliations. But the domestic assemblages, and the technological attributes (e.g., pottery forming techniques and temper preferences) that underlie the decorative, higher visibility attributes can indicate affiliations not consciously expressed (Stark et al. I998; see also Peeples 2018). This interaction between low visibility and high visibility signals is one way to look at how two axes of identity intersect. Others include how groups view violence, how they view outsiders, and whether they view progress or tradition as the natural state of society. Little of this has been explicitly discussed in the Gallina literature.

\section{Themes in Gallina Identity}

Until recently, Gallina archaeology has been focused on generalized reconstructions of culture history (see Constan and Bremer 20I7). Few investigations into social identity have explicitly been conducted. Even so, research has focused on some social attributes and processes that implicitly constitute axes of an interconnecting Gallina social identity. This work can be broken down into three themes ripe with potential for understanding how Gallina individuals and groups viewed themselves: (I) the isolation of the Gallina region from the rest of the northern Southwest, (2) the violence present in the region, and $(3)$ the "traditional" nature of Gallina material culture. 


\section{Isolation}

Early researchers perceived Gallina inhabitants as Cibolans fleeing Coronado in I 540 (Cope I 879:360-36I). Mera narrowed this Cibolan connection by claiming they were related to early Chacoan settlements in the San Juan area (I935:8), something argued later by Lange as well (I94I; see also Hibben [I949:I99]). Chacoan ceramics found in the Gallina region - often older than their associated settlements (Borck 20I2, 20I8)-suggested a connection between the Cibola region and the Gallina area to some early researchers (e.g., Green 1956:193). Based on excavations and survey in the Mesa Portales and Jones Canyon areas during the past 20 years, this connection became clear in a limited region at the edge of the Gallina heartland (Elyea 1994; Myers 2007), but the meaning of this admixture is just beginning to be explored (i.e., Borck 20I8; Simpson 2016).

Many early scholars believed the Gallina were interacting with, or at least strongly embedded in, the cultural dynamics of their contemporaries. For instance, Hibben saw clear connections between Gallina material culture and that of people from the San Juan and southwest Colorado (Hibben I939:266). Mera (I935:8) disagreed to some level, arguing instead that the Gallina were not related to Mesa Verdeans, but did seem to copy their design elements. Hibben (1949:199) later strengthened his disagreement with Mera by arguing that the similar use of carbon-based paint indicated a strong connection.

Cultural descent from earlier groups living to the northwest of the Gallina highlands were (and are) prominent discourses as well. This has frequently been shaped by arguments for the Gallina as derived from Rosa Phase (AD 700-850) people of the Upper San Juan region (Bahti 1949:58; Ellis I988:I4; Green I964; Green et al. I958:59; Hall I944; Mackey I977:48I; Mackey and Holbrook I975:84). These ancestral connections also led some researchers to look at potential descendent connections. Mostly, this was focused on demonstrating that the Gallina were proto-Jemez (e.g., Mackey I977; Reiter I938).

Scholars saw more than just local connections in Gallina material culture, though. Lange (I94I) inferred possible origins in the Great Basin and what we now call the Fremont region (I94I:I2; see also Bell [I940]; Green [I962:I 54]; Jennings et al. [I956:IOI-IO2]). Hibben believed that sandal designs indicated potential connections with people residing in the Kayenta region (1939:268-269). Hicks argued for links to Basketmaker III and Pueblo I period people in the La Plata District and Alkali Ridge in southeastern Utah (1949:5).

Some of these investigations into Gallina historic connections went a bit into the weeds as well. Hibben was responsible for a longstanding source of confusion in the literature when he incorrectly identified textured pottery as originating in Woodlands technological traditions (I949:200-20I) and possibly incorrectly identified some vessels as paddle-and-anvil finished instead of scraped (Hibben [I949:199], although see [1938:135] and [1949:202] for his concerns about the validity of some of these identifications). He also noted similarities in form between Gallina pointed bottom vessels and Navajo utility pots (Hibben 1949:200; see also Brugge [1983]), although he admitted there was no evidence to support this affiliation. 
Regardless of these connections, both inaccurate and accurate, the Gallina were often described by archaeologists as isolated from surrounding cultures (Cope I 879; Hibben I938, I939, I949:20I; Hicks I949:5-6; Lange [I956:82]). Loaded terms were used to describe their highlands environment. "Rugged, poorly watered" and "refuge country" stand as good examples (Schulman I950:293; see also Fiero [I978:215]). This terminology helped form opinions of the Gallina people as backwards and having "developed only a rudimentary and belated form of Anasazi culture, little influenced by the achievements of their neighbors" (Green I962:154). In short, the Gallina were seen to inhabit an inhospitable land (Stuart and Gauthier I98I:40-42) either by choice or as involuntary victims of the times who were left behind by their more progressive neighbors.

The charged nature of the isolationist terminology used to describe the Gallina carries over to the physical environment. These labels imply that people must have been forced to live in a marginal and unsustainable world. However, research during the past 30 years has shown that while cycles of aridity occurred (Holbrook and Mackey 1976), based on the analyzed skeletons of Gallina individuals from multiple burial contexts, health was good. The Gallina were relatively well-off with normal levels of pathological infections (Stodder I989:Table 45) and a good diet (e.g., Fiero 1978:204).

Many scholars in the region understood that the Gallina were well-connected amongst themselves, possibly through a large-scale tower communication system (Byrd 2016; Sleeter 1987), but few argued for strong connections to external groups (although see Borck 20I2; Ellis I976; Simpson 2008) beyond the early hypotheses noted above. While there is a southern component near the modern New Mexican town of Cuba where Cibolan and Gallina material culture mix within archaeological communities (Elyea I994; Myers 2007), these relationships did not filter into the Gallina heartland. Indeed, these relationships may have even isolated Gallina individuals interacting and living with Cibolan groups from those in the Gallina heartland through the social enforcement of prohibitions or taboos against contact with outsiders (Borck 20I8:I34-I35).

\section{Violence}

Violence is endemic in all societies to some degree, but its scale and frequency can indicate how individuals and groups view conflict. Since the earliest tentative explanations for the Gallina region as a Cibolan place of refuge from the violent and oppressive arrival of the Spanish (Cope I879:360-36I), to Hibben's excavations and discovery of perimortem trauma on many skeletal remains (I939), to Ellis uncovering individuals burned alive in habitation structures (I976), violence has permeated how archaeologists discuss Gallina society. The Gallina region has been called "the most convincing and diverse evidence yet documented for violence during Pueblo III" (Wilcox and Haas I994:2I6) where "violence and violent death were a ... way of life" (Chase I978:32). This view of them as the stereotypic, violent "hill people" (Wilcox and Haas I994:2I4) was reified through citation chains until it defined them as a culture. At the height of searching for "the worst," something archaeologists like to do when they are not searching for "the first," some even 
argued that Gallina society was rife with "chaos and social pathology" (Turner et al. 1993:107). Mad Max met Thomas Hobbes and the Gallina narrative was penned.

\section{Traditional}

The final thematic trend implicit in discussions of Gallina social identity is the "traditional" nature of their material culture. This partially revolves around ceramic conservatism where form and stylistic changes through time in Gallina ceramics are argued to be minimal to non-existent (e.g., Hibben 1948). The lack of trade goods, especially ceramics, has also been employed to justify an interpretation of the Gallina as avoided by, or avoiding, their progressive neighbors. Some researchers maintain that the technological and stylistic homogeneity present in Gallina ceramics is a false product of excavator bias and methodology (Snow 1978). Nonetheless, the preponderance of evidence at this stage indicates that it is a real pattern to an extent.

Architecture has been used to interpret the Gallina as overtly traditional as well (e.g., Hibben 1949). This has also been leveraged to present them as unaware of the contemporary changes in the social worlds of other groups in the northern Southwest (Green 1962:154). While other Pueblo groups made the transition from pit houses to aboveground structures and pueblos circa AD 900, the Gallina constructed residential pit houses until the region was depopulated at approximately $\mathrm{AD}$ I 300 . Surface houses with the same internal lay out as pit houses were often inhabited at the same time as their subterranean counterparts (Douglass 1917:8; Green 1956:193; Hibben 1939:5I-52, I948; Mera 1935). These structures were frequently built near each other, so the choice to build above or below ground is not simply one of soil depth or other environmental considerations.

In general, the internal layout of Gallina habitation structures is remarkably standardized. The houses are comprised of banquettes, wing bins, a hearth, an auxiliary ash pit, and a U-shaped deflector (Dick I976; Simpson 2008). Sub-hearth features have been found (Ellis I99I:72) and were likely related to either a construction blessing or the ceremonial function of the structure. Ellis interpreted these as sipapus, but they are quite different from sipapus found in kiva structures in other areas of the Pueblo world (Ellis I988; Hayden I978 for an extended discussion).

The pit structure transition from generalized habitation and ceremonial use to specialized ceremonial use noted elsewhere in the Pueblo world never occurred in the Gallina area (Dick I980:61; Douglass 1917:8; Green 1956:193, I964:3 I-33; Pattison I968:I26-I27). Some have argued that the lack of sipapus indicate that Gallina pit houses were not ceremonial (e.g., Green I956:193), but most archaeologists in the region disagree. Instead, the presence of banquettes and murals suggest that habitation structures likely served both residential and ceremonial functions (Green 1964:39; Hibben 1938:133; Kliendienst 1956; Lange 1956; Mackey and Green I979:I 50; Mackey and Holbrook 1975:73; Pattison I968:I 26-I 27).

\section{Multiple, Intersecting Axes of Identity in the Gallina Region}

One of the first explicit uses of the term identity in Gallina research is in a 1948 University of New Mexico, Department of Anthropology master's thesis by Vera 
Koehring. Through the course of her art historical investigation into the structural nature of decorative styles on Gallina ceramics, Koehring confronted many of the stereotypes of the Gallina as isolated and backwards. She drew heavily on music theory and the cultural relativism of Boas. Depending on your perspective, her work-much like her research subject-was both behind and ahead of her times. That her thesis was not published is one of the great travesties of Southwestern archaeology.

Koehring used the nature of artistry in the region to explore Gallina social identity.

So we are ready to ask again ... who were the Gallina? They were a people for whom tradition was not bondage, nor was it altogether narrow in scope. They had very little in the way of detail, but what they had was so incorporated as to seem significant. (I948:47)

But Koehring did not simply examine the sparseness of esthetics, she wanted to understand Gallina identity from the perspective of the artist rather than from our contemporary vantage point that finds beauty in balance and invention. She argued that "all Gallina lines are like unadorned beams or rafters; the history of structure is exemplified; a strength stands out; and the result is satisfactory design. If a mind appreciated structural traditions, these austere bowls were and are beautiful" (Koehring I948:9). Thus, Gallina social identity existed in an infinite now where structure and tradition - valued the way Western society values balance and innovation - dialogically recreated each other.

Another explicit use of identity can be found in Wiseman's (2007:205-207) analysis of habitation rooms as identity markers linking the Gallina and Ancestral Jemez archaeological records. While it is unlikely that the Gallina immigrated to a single location (Beal I987; Borck 2012:25-26; Simpson 2016:272; and O'Donnell and Ragsdale 2017), a few researchers have focused on Jemez (Ellis I988; Ford et al. I972; Mackey I982; Reiter I938). This interpretation has significant problems however (see Constan and Bremer 20I7) and is not accepted by most Gallina archaeologists.

As noted earlier, the Gallina are often linked with groups populating the Upper San Juan region. People inhabiting this region during the Basketmaker II and III periods (400 BC-AD 700) (Charles et al. 2006) were similar, yet distinct from those farther west throughout the Mesa Verde region (e.g., Charles and Cole 2006). By the early AD 70os, Upper San Juan groups were participating in panregional ceramic and architectural traditions similar to neighboring groups. This changed in the mid-AD 700 s as dramatic organizational changes began west of the Upper San Juan - in the Mesa Verde region - that redefined households, communities, and social power across a vast area (Wilshusen et al. 20I2). Communities were transformed from scattered homesteads with residential pit structures, surface storage buildings, and accessible kivas to aggregated pueblo villages with surface level residential apartments and kivas with restricted access. The significance of these organizational shifts cannot be overstated. Along with similar experiments in the late Basketmaker period, like at Shabik'eschee (Wills et al. 20I2), these 
changes would provide the foundation for the rise of hierarchy throughout the Four Corners, particularly at the height of Chaco (Lekson 2006) and then later throughout the Mesa Verde region (Arakawa 20I2; Glowacki 2015).

During this dynamic period in the AD 7oos, Upper San Juan inhabitants, however, continued earlier cultural patterns with little interruption. They lived in pit structure homesteads, possibly taking in nonconforming and displaced populations from rapidly changing societies in neighboring regions. A social identity emerged that strongly opposed the organizational changes to the west that trended toward increased hierarchy (Simpson 20I6). It may not seem remarkable that a people developed an identity simply by not changing in step with those in a nearby region, but given the massive and all-encompassing nature of the changes occurring all around them, not conforming must have been an act of rebellion or active resistance.

Groups living throughout the Four Corners that opposed the changing social situation often faced deadly consequences (Potter and Chuipka 20IO). This conflict eventually led to Upper San Juan populations moving east and south while groups in the La Plata and Dolores areas within the Mesa Verde region and closest to the Upper San Juan moved west (Eddy I966, I974; Potter et al. 20I2). People eventually left the Mesa Verde villages by the late AD 800s (Wilshusen et al. 20I2). Some stayed in the northern and western portions of the Mesa Verde region, but many went south (Coffey 2006; Windes and Van Dyke 20I2). This, in conjunction with southern locals, may have been the impetus for what would eventually emerge as the hierarchical Chacoan world (Wilshusen and Van Dyke 2006). These two movements-of groups away from the Upper San Juan and then from groups out of the greater Mesa Verde region-buffered Upper San Juan communities from violent reprisals for not following their cultural trajectories (Simpson 20I6).

Between AD 900 and Io00, a unitary Upper San Juan identity becomes harder to recognize in the archaeological record. This branching may have happened slowly as the large Northern San Juan/Mesa Verde villages that had previously acted as a stimulus for the development of a strong Upper San Juan identity were depopulated. Innovation flourished, as can be seen in changing ceramic designs, types, and architectural styles (Bellorado 20I3; Simpson 2008).

In $\mathrm{AD}$ I076, a Chacoan style building was built at Chimney Rock within an Upper San Juan community (Malville 2004). It was a structure different than any other in the Upper San Juan and clearly attributable to non-local builders (Matlock and Malville 1993). Unlike with previous changes resisted by Upper San Juan residents, this one drew them in. It is unclear if the relationship between the Chimney Rock Pueblo builders and the locals was one in which the locals were reluctant, or forced, participants, or if they invited Chacoan builders (Chuipka and Fetterman 20I3; Malville 2004; Todd 20I2), but the end of the period in this region was dramatic.

Based on the lack of dates associated with the next lunar standstill in AD I I I I, it is probable the Chimney Rock world changed around AD I Ioo (Simpson 20I6). This transformation is associated with at least some violence (e.g., Jeancon 1922; Roberts I930; Simpson 20I6). The result, though, is what appears to be the depopulation of the entire area and, for the first time in over I,oo० years, there is little evidence for occupation in the Upper San Juan north of the San Juan River. Many groups probably 
moved south to the Gallina area and joined others who had possibly resettled there starting in the AD 9oos (Chuipka and Fetterman 2013; Eddy 1966, I974).

Unsurprisingly, history lays a heavy potter's hand on the shaping of "the present." The Gallina people's historical context adds weight and purpose to their story. They were neither forgotten hillbillies, nor emergent rebels. They were fully contextualized within a social identity defined by resistance to cyclical hierarchical processes (e.g., Arakawa 201 2). Their shared history with their neighbors indicates they were reacting to changing socio-political patterns, which of course demonstrates that they had knowledge of contemporaneous politics as well.

The above discussion sketches a historical path that we can use to make social inferences. Shared histories and divergent paths help us find connections through their conspicuous absences when comparing regions (Fowles 2010). These absences can indicate taboo (Fowles 2008) or forgetting (Borck 20I8). Both social processes are powerful indicators of negative signatories (e.g., Halbwachs I992:I72) that undergird patterns in the material record and are strongly entwined with history and the past (sensu Lowenthal I985).

Thus, Gallina social identity is not simply about how they interacted with, or avoided, their neighbors. It is also about how they interacted with their past. Borck (2018) argues that the rare examples of foreign sherds in the Gallina region (many of which predate the Gallina inhabitation and were likely curated) are much more than simple evidence that the Gallina were isolated and disconnected. Instead, he argues that soil from distant places was embedded in their matrix and that they were physical attachments to previous places and diverse histories. Similar to some contemporary Pueblo groups (e.g., Colwell-Chanthaphonh and Ferguson 2006), these historic artifacts were memory pieces.

In the Gallina heartland, where the basic pattern is for an individual site to be associated with sherds originating from only one direction (of production), these sherds may represent fragments of other places and other times, fragments of a household's history, a family's social memory inscribed onto a portable artifact. (Borck 20I8:I34; see also Constan [20II:I7I])

The distribution of these sherds, along with a connection to where they were originally produced, creates a memory map (Figure I) that can be viewed as a networked history. A map of where at least some folks from the area came from. So, while most Gallina households likely originated in the Upper San Juan, it seems likely that some came from elsewhere as well, drawn by a common desire to resist the hegemonic processes of the day. This movement was similar perhaps to the incorporation of other peoples into communities resisting centralizing changes during the AD 7005 in the Upper San Juan (Chuipka and Fetterman 2013; Simpson 2016).

Material cultural similarities between the Gallina and neighboring groups are present as well, of course (Simpson 2008, 20I6). These physical links, along with the historical ones noted above, point to broader interactions with contemporary ideas (Hays-Gilpin and Hill I999; see also Bellorado 20I7), languages (Ortman 2OI2), and a sophisticated understanding of religious and political fluctuations. These underscore that the Gallina were very aware of their neighbors and purposely 


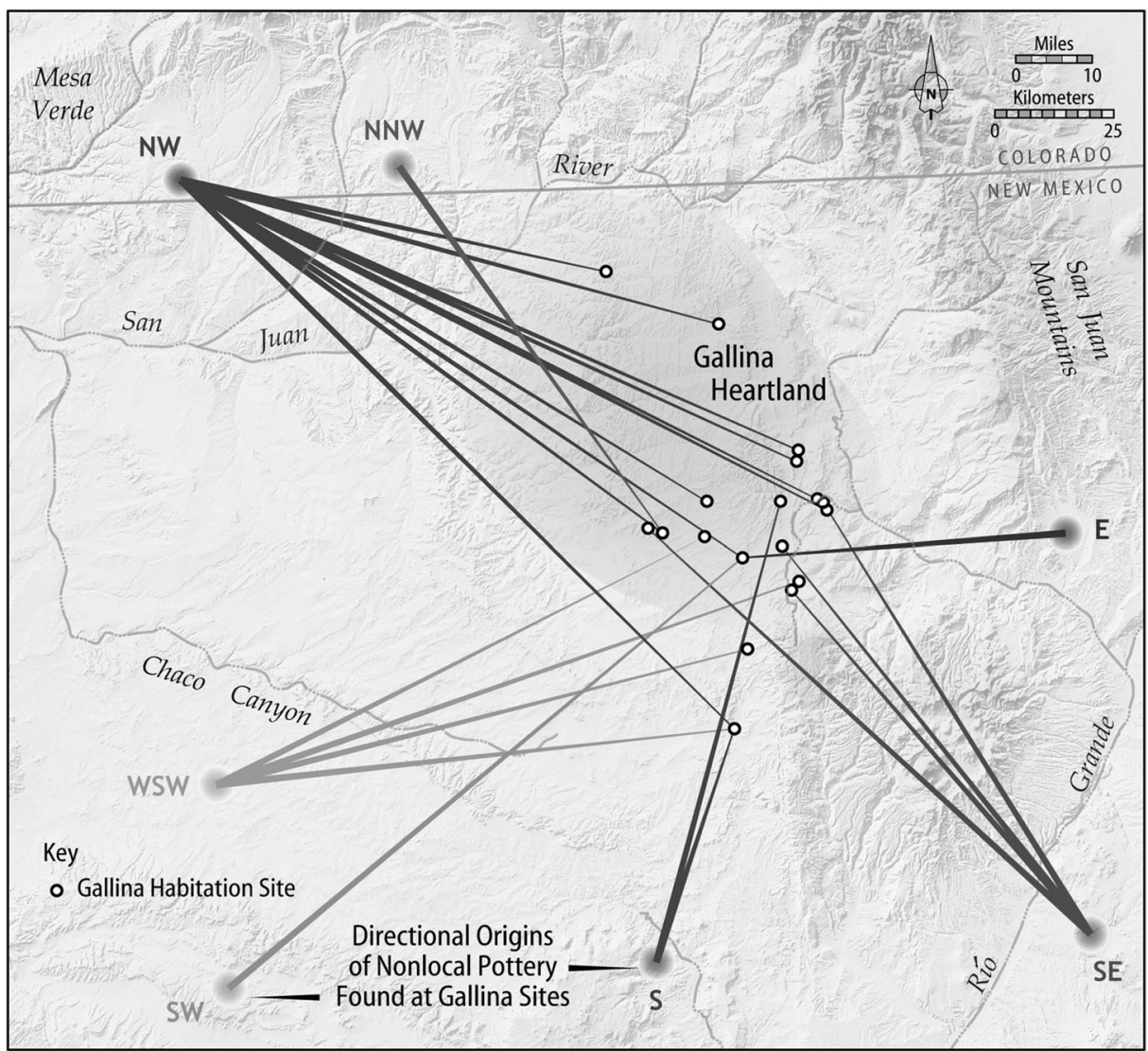

Figure 1. Two-mode social network for the Gallina region, excluding the Mesa Portales and Jones Canyon regions. Gray circular nodes are directions of production for non-local ceramics in the Gallina region, and white circular nodes are individual archaeological sites. Archaeological sites are geo-referenced, and directions of production nodes are located at the corresponding point to their direction from the Gallina region. This map forms a Gallina memory map, or really a map of forgetting (see Borck [2018] for an in-depth discussion of this process). Image by Catherine Gilman.

isolated themselves in their highland homes (Borck 201 2:62-63, 2018; Green I956; Simpson 2016:273; see also Kocer 2017). Contextualized both with their history, and how they interacted with this past, the Gallina emerge as a sophisticated group living within a cycling system of conflict over the rights of individuals or groups to control the lives of others - of resistance to hierarchical processes.

As our understanding of how Gallina individuals and communities were connected to the broader cultural, religious, and political world has changed, so too has our understanding of violence in the region. As discussed above, the evidence for deadly conflict in the area has been used to caricature the Gallina people as a society of violent sociopaths (e.g., Turner et al. 1993). Thus, our ideas of why violence happened there dramatically impact our understanding of Gallina social identity, and apparently their mental health. 
Since conflict and violence are regulated by cultural rules (Keeley I996), prolonged societal chaos arising from violence is unlikely. Similarly, social pathology is actually a deviation from the rules of society (Sutherland I945:429), so if the rule of society was violence, it would hardly be pathological to follow suit. As the sociologist Becker (2008) has demonstrated, deviant societies follow similar social rules as those in the societies from which they diverge. Moreover, we now know that the Gallina region did not witness the most violence in the northern Southwest during the Pueblo III period (Kuckelman and Martin 20I2), or even in the last few hundred years (Kohler et al. 20I4).

While an in-depth review of evidence for Gallina violence is beyond the scope of this article (see Borck 20I2:17-22 for a detailed overview), it is clear violence occurred at multiple settlements and intervals. Much of the research has focused on whether it arose as internecine conflict among neighboring Gallina communities (e.g., Ellis 1976:8-9; Hicks 1949:6; Mackey and Holbrook 1975:75; Schulman I950:296) or between Gallina communities and non-Gallina groups (Hall I944; Hibben I939:228-229). Research on alliance building within the Gallina world (i.e., Byrd 2016; Sleeter I987) indicates that while conflict between communities may have been possible, widespread killing is less likely.

Instead, violent fatalities in the region appear to mostly result from conflict between Gallina and non-Gallina groups. This is supported by work that statistically correlates the location of archaeological sites that had individuals with fatal perimortem wounds with possible migration paths from the Mesa Verde areas in the mid to late AD I 200 s (Borck 20I 2:42-50). These findings are supported by work demonstrating no changes in preference for clay acquisition among potters during periods of violence in the Gallina region (Constan 20II). Coupled with our understanding that modern people in conflict zones perceive leaving their village as unsafe and that their safety increases with more economic resources at their village (Maxwell et al. 2017:5), this pattern indicates that while at least two periods of violence in the Gallina region existed (see Borck 20I2), it is unlikely that violence was a daily concern. The choices of Gallina potters do not indicate that.

Not all interactions between Gallina communities were peaceful, though, and at least one example where multiple individuals were killed is likely the product of violence between Gallina communities (Borck 20I 2:46-47; Ellis I976:8-9). So as with everything in this region, the answer is more shaded than black-and-white.

As with isolation and violence, our understanding of Gallina traditionalism has complicated the earlier binary of either in-touch or left behind. Much of this change in thought comes from a better understanding of the seemingly contradictory static and inventive nature of traditions. Invented traditions are practices that are governed by ritualistic and symbolic rules (Hobsbawm I992). These practiced traditions attempt to indoctrinate certain values and norms of behavior into a population through repetition. These traditions automatically imply a continuity with the past, although they are not necessarily part of the past. They are more a material conversation with past. This conversation creates a materialistic historical narrative. This history then emerges within cultural discourses and imposes fixed, often formalized, practices on society (Hobsbawm I992:I). These invented traditions 
produce an impression of continuity, stability, and shared identity that projects backwards into earlier times (Lewis and Hammer 2007:5-6) and so they are powerful ideological tools for political action that frequently serve a group interest (Tonkinson 2000:I70).

The introduction of the pointed bottom jars to the Gallina region sometime after the Rosa Phase, possibly as early as AD rooo (Bahti I949; Hall I944:Appendix G), is evidence of an invented tradition in the area. Ceramic vessels with this conical base form are frequently associated with nomadic groups across the globe (Helton-Croll 2010). Focusing on North America, Mills (I985:Table I) prepared an analysis of utility ceramic forms, subsistence practices, and settlement patterns of 37 groups. Of these groups, eight used, at least partially, ceramics with pointed bases. These groups all practiced either a gathering-hunting lifestyle $(n=6)$ or a mixed gathering-hunting and agricultural lifestyle $(n=2)$.

The Gallina, though, were settled agriculturalists. While they used logistical camps, they were not continually on the move. Cross-culturally, they do not fit the pattern for groups that would employ this form of ceramic vessels. They did, however, use the pointed bottom pot for similar purposes. Most of these vessels are covered in soot (Constan 20I I; Hayden I978:36; Hibben I949; Kocer 20I4; Mackey and Holbrook 1975), suggesting that they were frequently used for cooking. Moreover, Constan (2OII:I56) suggests that the pointed bottom pots may have been used specifically for cooking wild resources instead of cultigens.

In the Gallina region, the pointed bottom pot is accepted at all sites in an archaeological instant and remained one of the dominant utility forms during this period. This may be a deliberate introduction of a pottery tradition that draws connections to a semi-mythical history, possibly by drawing on similarities in form to conical burden baskets (e.g., Guernsey and Kidder I92I). This follows a tendency in Pueblo society to model ceramics after basketry that has previously been reported upon (e.g., Cushing I 886:483). Or, coupled with the heavy reliance on game meat in the Gallina region (e.g., Ellis I988; Fiero I978), this vessel shape was deployed to institute a revitalization of a hunter-based past along with its associated cuisine. Either way, this is an emergent material tradition within Gallina culture focused on an ideological past that likely facilitated a disassociation from increasingly hierarchical Chacoan and, later, Mesa Verdean organizations through the construction of a materialistic historic narrative.

Pit houses continued to be occupied for domestic purposes in the Gallina region, as well. The Gallina people lived in pit houses long after even neighboring "out-of-phase" groups (Stuart and Farwell 1983), such as Taos, transitioned to aggregated pueblos and specialized ceremonial pit structures. Gallina pit houses were built alongside newer structural forms initially developed in the Chimney Rock area, including thick-walled residential surface structures, gridded storage buildings, and towers (Eddy I977). This co-occurrence in architectural forms indicates that the continued use of pit houses in this highland environment is not merely an environmental adaptation.

During the Gallina Phase though a new interior design style emerged for all residential structures, both pit houses and the thick-walled surface structures (Simpson 2008). The surface houses were essentially an above-ground version of a 
subterranean pit house having only access via the roof and a ventilation shaft to regulate air flow. This mirroring of the new surface structure form to the traditional pit house is unique to the Gallina. In other areas the internal layout changes with the transition to surface structures.

These pit houses, in essence, are another material presence from a constructed history that are interjected into the present during the daily activities of the Gallina people. Like the pointed bottom vessels, these structures were statements of Gallina identity in a world, which to the Gallina, may have appeared to be moving in the wrong direction. In a similar way that the Salado ceramic horizon in the Hohokam region was employed to unify diverse groups of people under a forward-looking (Borck 20I6) and cohesive framework (Clark et al. 2013), the Gallina used these two meaning laden objects to unify their communities.

This material view to the past for guidance is also visible in village structure, reduced production of corrugated ceramics, and lack of mineral paint in the Gallina region. Using the Room Contiguity Index (RCI) (Clark 200I) that can distinguish spatial practices through an analysis of shared walls, Figure 2 (see Borck 20I8:I37-I4I for an in-depth discussion) displays a trend through time toward centralization and aggregation that begins with a dispersed pattern of spatial organization in the Basketmaker II period. The remarkable social reorganization during the Pit House-to-Pueblo transition is startling when comparing RCIs across the Basketmaker III-Pueblo I divide. Even the massive aggregation at the beginning of the Pueblo IV period fails to produce such a scale of difference. Viewed from an RCI perspective, the Pit House-to-Pueblo transition was a dramatic societal rupture in how people thought that social space, and thus community, should be organized. It is to this period that the Gallina looked to model the revitalization of society.

Moreover, the Gallina built a non-specialized and decentralized ritual system in which each domestic structure was likely used for ritual purposes (Borck 2018:I37-I39; Dick I980:6I; Green I956:I93; Pattison I968:I26-I27). This opposed the contemporaneous trend in the northern Southwest where domestic and ritual space were sundered, giving rise to the increased power of ritual specialists. In a very real way, the Gallina used architecture and community layout to restructure their society in a direct reference to the distant past that was simultaneously a critique of the hierarchical social and ritual practices of their neighbors.

This use of the past to reform the present is likely to have contributed to the loss of certain ceramic attributes in the Gallina region as well, particularly corrugated vessels and mineral paint. Corrugated utility ceramics are a hallmark of Pueblo II and III period assemblages (e.g., Pierce 2005). They were introduced into the Upper San Juan region by AD 975 (Reed and Goff 2007) and would come to be the dominant utilitarian vessel type (Figure 3). This though would quickly change after Upper San Juan populations shifted south of the San Juan River. Gallina utilitarian assemblages typically have no corrugated ceramics and those that do are generally in the northern portions of the Gallina area and possibly date to early in the Gallina Phase (Knight I990). Corrugated ceramics do occur on sites in the extreme southern limits of the area occupied by the Gallina, but these have been interpreted as trade items from nearby Cibolan peoples (Wilson I994). 


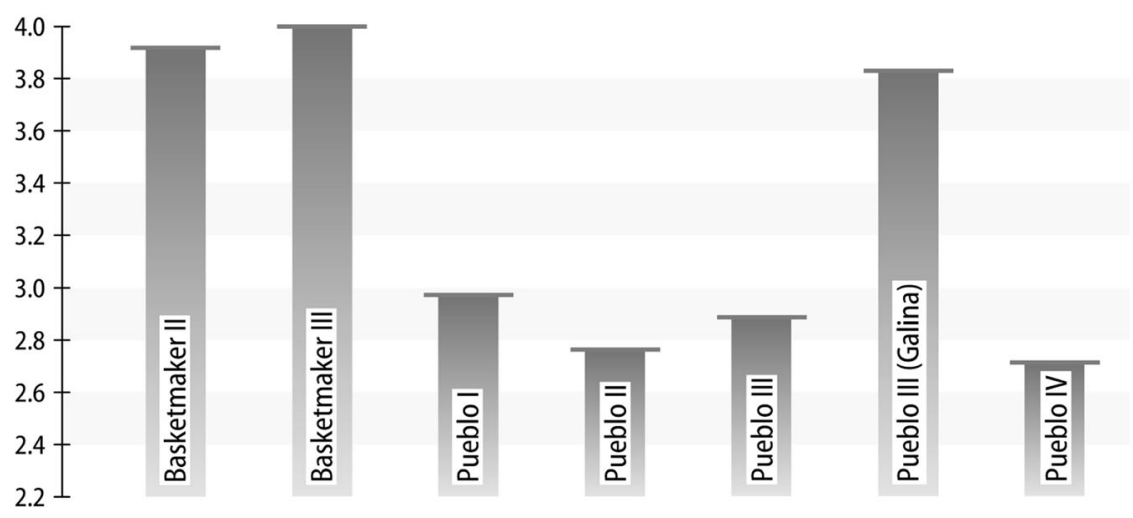

Figure 2. Histogram of average RCls (number of room walls divided by number of rooms, counting each wall only once) across temporal periods in the northern U.S. Southwest from approximately $1500 B C$ to $A D 1500$. $R C l$ ranges from 2 (square room block of infinite size) to 4 (complete non-contiguity). Lower numbers reflect more contiguous spatial organization and reduced household autonomy. See Borck (2018:137-141), Figure 4.7 for an expanded explanation. Figure by Catherine Gilman.

Similar to this decline in corrugated ceramics, mineral-based paints used for decorating ceramic vessels also sharply drops off in use early in the Gallina Phase. Figure 4 shows a steady increase in mineral paints for Upper San Juan populations up until the beginning of the Gallina Phase when its use all but disappears. Sites in the northern portion of the Gallina area are more likely to have mineral paint (Knight I990) similar to the pattern of corrugated ceramics in these potentially early Gallina Phase sites in areas that would have been initially occupied by people moving south from the Chimney Rock area.

\section{Discussion}

Archaeologists working on the material culture left by the Gallina people are revealing a society that is much more complicated, even contradictory, than earlier research had demonstrated. They were a group for who conflict was not rare, but who did not live in a state of perpetual violence. They moved to the highlands west of the Rio Chama not because they were left behind, but because they choose to use movement as a means to resist increasing hierarchy in the Four Corners (sensu Sassaman 200I). While materially disconnected, they were simultaneously connected historically and fully aware of how societies around them were changing.

The Gallina forged their social identity around a deep respect for traditionalism through a connection with the past and the creating of history. They built their society around structure (sensu Koehring I948) to ensure the replication of those traditions for their children. This traditional identity was embedded in the history of regional resistance to centralizing political practices (Simpson 20I6), but flourished as the Gallina emerged as a large-scale horizontally oriented social movement in the northern Southwest (Borck 20I8). 


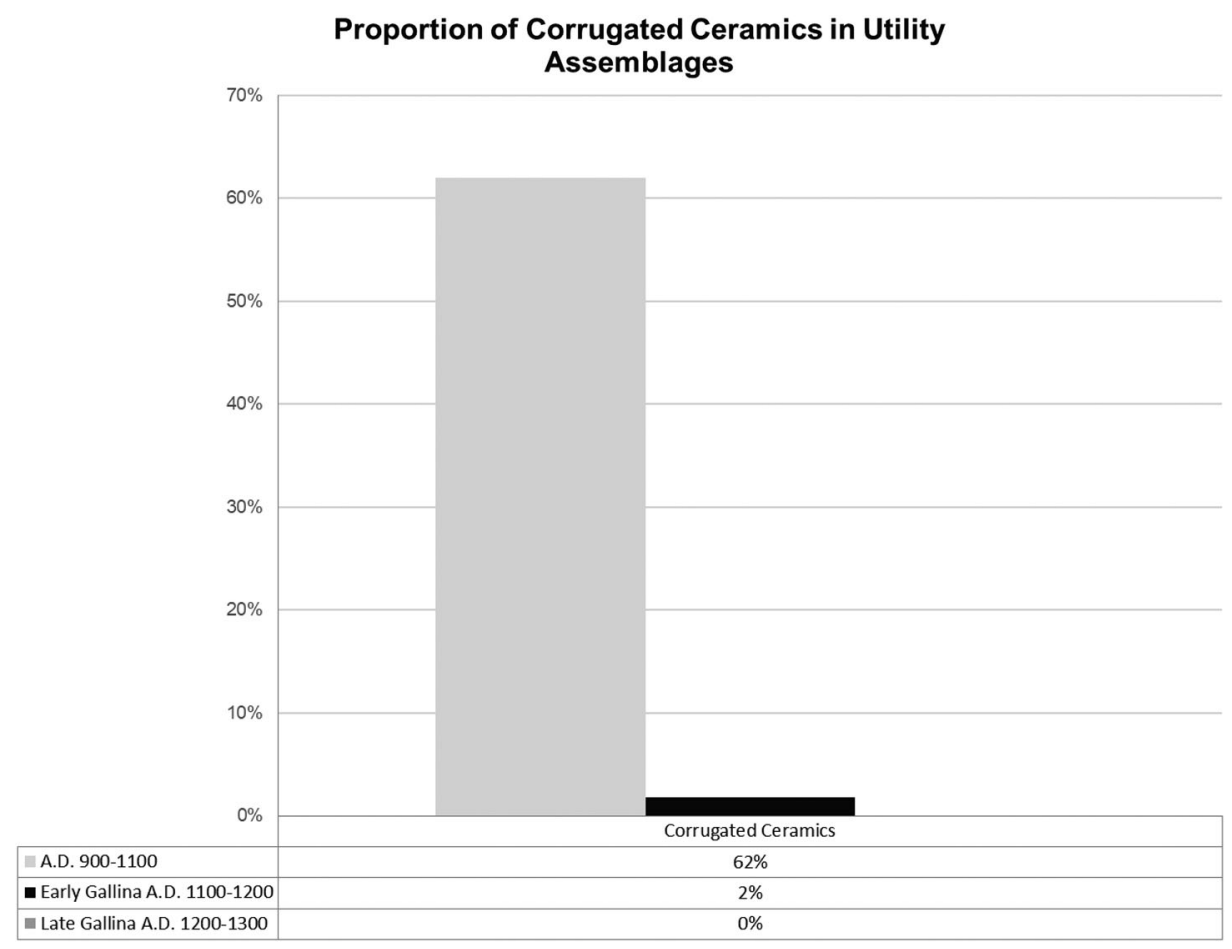

Figure 3. Changes in proportion of corrugated ceramics through time in the San Juan region. Early Gallina is approximately AD $1100-1200$ and Late Gallina is approximately AD 12001300. Data from Simpson 2014.

As noted by Emerson and Pauketat, archaeologists often narrowly interpret power as a "thing to be possessed, lost, or overcome" (2002:105). This emerges from our cultural position in Western society, which itself sees power as "primarily negative, coercive, repressive, immoral, elite related, held by the few, and exercised over the many" (Emerson and Pauketat 2002:I05). Power, however, is everywhere and in every relationship. We are constantly subjected to it and subjecting it (Foucault I978:93-96). And it is not simply negative. It has the potential to create beneficial change in society, not just aggrandizement and control over others. But instead, power can be the ability to act together to limit the centralization of power (Clastres 2007).

The Gallina mobilized their historical "identity of resistance" (Simpson 20I6:I60) and "used the concept of stability to enact a revolution" (Borck 2OI 2:6I). This identity was purposefully strengthened and broadened to contest the increasing levels of hierarchy and control of religious practices by fewer individuals in the Four Corners. Borck (2018), using the Gallina, called this type of bottom-up oriented, anti-authoritarian social movement focused on historical (real or constructed) tendencies an "atavistic social movement," something oppositional to the revivalistic form of Wallace's more well-known, authoritarian revitalization movements (Wallace I956). 


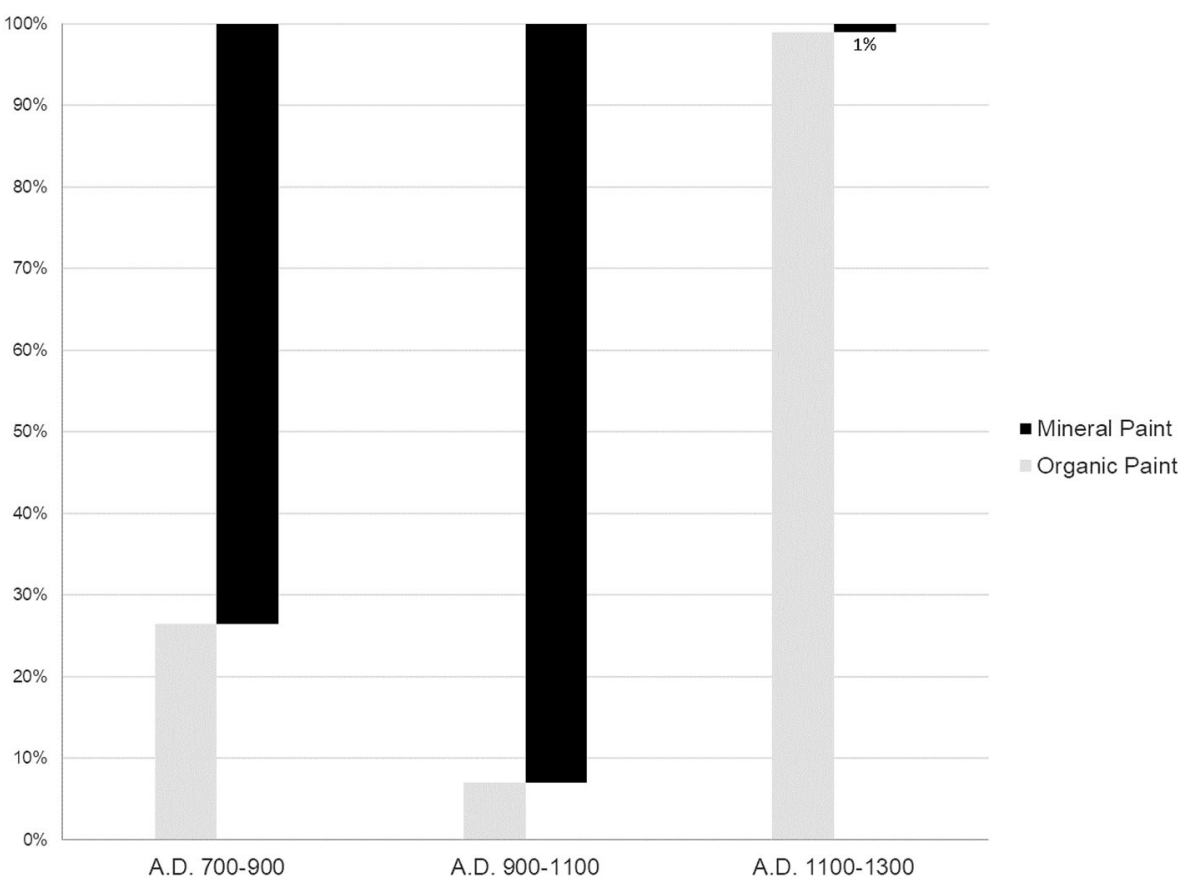

Figure 4. Changing proportions of organic versus mineral paint in the upper san juan and gallina. Data from Simpson 2016.

It is perhaps significant, that with the rejection of hierarchy in the Four Corners, the Gallina material culture footprint that replicated the social drive for Gallina resistance to this authoritarianism was quickly lost. This material culture crafted an identity that looked to the past, to create resistance in the present, and prefigure (e.g., Franks 20I4) a future society along more equitable principles. "By appropriating the past for their own intentions, they [became] rebels in their present-pioneers of a future history" (Borck 2018:148).

The strong reliance that Gallina people had on their history, itself a social construct, is particularly important for understanding their social identity. As Koehring noted, their material culture highlights a reliance on structure and lack of change (1948), but this is placed within a context of invention and reorganization. For example, "saviors of the past change it no less than iconoclasts bent on its destruction" (Lowenthal I985:4IO). While the Gallina crafted change, the past-facing, instead of forward-looking, tools they used to create that change demonstrates that social identity in the Gallina region was clearly not looking to create progress.

In many ways, we would define this as process-oriented, a form of ethnogenesis (Weik 20I4), because change was happening and identity was being constructed around that change. Yet this fails to incorporate how the Gallina may have seen themselves. After all, their social identity was not about change (although it happened), but was instead crafted around limiting change in the wrong direction. Therefore, the process-oriented discussion of ethnogenesis can be problematic. Instead it might be best to think of Gallina social identity as one of being, instead 
of becoming, because for them identity was not a process, it was a position, although one variably shifting along intersecting axes of identity - it was not static. Just as critically, becoming is a category of hierarchical power in some Indigenous communities in the Southwest. Ortiz (1969:79) describes this for the Tewa Patowa (which can be translated as Become or Made People), "they control and direct all group ritual activities and stand as the real powers behind the political officials." Constantly Being, but never Becoming, accurately portrays the Gallina as the wonderfully disparate and contradictory group that they were-sophisticated rebels using the past to limit the rise of hierarchy.

\section{Acknowledgments}

Thanks to J. Michael Bremer who has graciously discussed this topic with both of us for a bit over a decade now, as well to two anonymous peer reviewers. Many thanks are also owed to Lexi Klann who helped transcribe the very difficult to read pdf version of Vera Koehring's thesis that researchers have been squinting at for decades now.

\section{Funding}

Portions of Borck's research was funded by an Haury Fellowship through the School of Anthropology at the University of Arizona, a Preservation Fellowship at Archaeology Southwest, and National Science Foundation Grant \# I 52285 I.

\section{References}

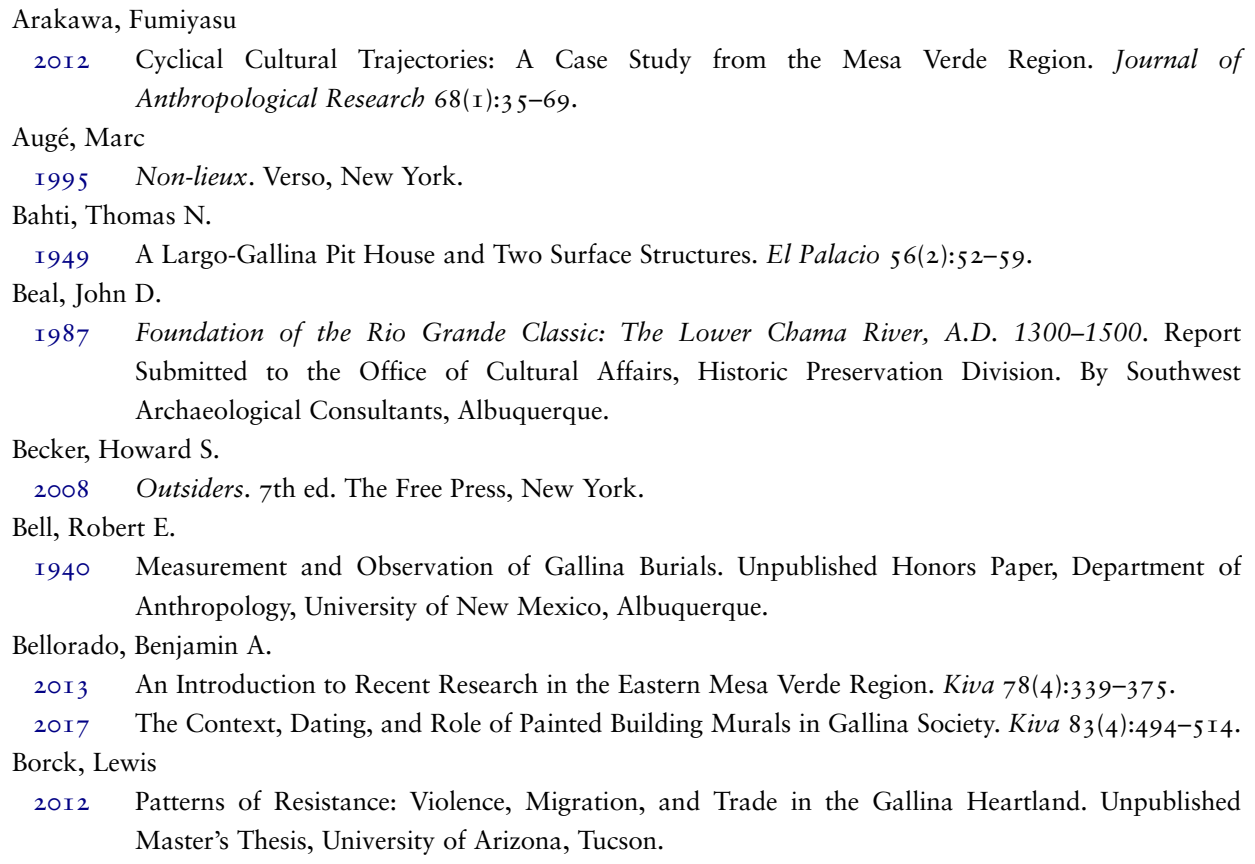


2016 Lost Voices Found: An Archaeology of Contentious Politics in the Greater Southwest, A.D. I IooI 450. Unpublished PhD Dissertation, School of Anthropology, University of Arizona, Tucson.

2017 Connected and Isolated: A Discussion about Gallina Archaeology with No Resolutions. Kiva 83 (4):443-449.

2018 Sophisticated Rebels: Meaning Maps and Settlement Structure as Evidence for a Social Movement in the Gallina Region of the North American Southwest. In Life Beyond the Boundaries: Constructing Identity in Edge Regions of the North American Southwest, edited by Karen G. Harry and Sarah Herr, pp. I 18-164. University Press of Colorado, Boulder.

Bremer, Michael, and Denver Burns

20I3 Living It Up: Upland Adaptation and High Altitude Occupation by Ancestral Pueblo People During the Gallina Phase Along the Continental Divide. In From Mountain Top to Valley Bottom: Understanding Past Land Use in the Northern Rio Grande Valley, New Mexico, edited by

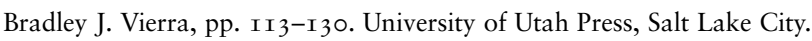

Brugge, David M.

I983 Navajo Prehistory and History to I 850 . In Handbook of North American Indians, edited by Alfonso Ortiz, pp. 489-50I. Smithsonian Institution, Washington, DC.

Byrd, Adam Muir

2016 A GIS-Based Investigation into Social Violence and Settlement Patterns in the Gallina Area of the American Southwest. Unpublished PhD Dissertation, The University of New Mexico, Albuquerque.

Carr, Christopher

I995 A Unified Middle-Range Theory of Artifact Design. In Style, Society, and Person: Archaeological and Ethnological Perspectives, edited by Christopher Carr and Jill E. Neitzel, pp. I7I-258. Plenum Press, New York.

Charles, Mona C., and Sally J. Cole

2006 Chronology and Cultural Variation in Basketmaker II. Kiva 72(2):167-216.

Charles, Mona C., Leslie M. Sesler, and Timothy D. Hovezak

2006 Understanding Eastern Basketmaker II Chronology and Migrations. Kiva 72(2):217-238.

Chase, James E.

I978 North Central New Mexico Gallina: Analysis and Comparative Study of Their Physical Remains. Unpublished Master's Thesis, Colorado State University, Fort Collins.

Chuipka, Jason, and Jerry Fetterman

20I3 Examining Orthodoxy in the Upper San Juan Region of the Northern Southwest. Kiva 78(4):449-476. Clark, Jeffery J.

200I Tracking Prehistoric Migrations: Pueblo Settlers Among the Tonto Basin Hohokam. Anthropological Papers of the University of Arizona No. 65. University of Arizona Press, Tucson.

Clark, Jeffery J., Deborah Huntley, J. Brett Hill, and Patrick D. Lyons

20I3 The Kayenta Diaspora and Salado Meta-Identity in the Late Pre-Contact U.S. Southwest. In Hybrid Material Culture: The Archaeology of Syncretism and Ethnogenesis, pp. 399-424. Occasional Paper No. 39. Center for Archaeological Investigations, Southern Illinois University, Carbondale.

Clastres, Pierre

2007 Society Against the State: Essays in Political Anthropology. 6th ed. Zone Books, New York.

Coffey, Grant

2006 Reevaluating Regional Migration in the Northern San Juan During the Late Pueblo I Period: A Reconnaissance Survey of the East Dove Creek Area. Kiva 72(I):5 5-70.

Colwell-Chanthaphonh, Chip, and T. J. Ferguson

2006 Memory Pieces and Footprints: Multivocality and the Meanings of Ancient Times and Ancestral Places Among the Zuni and Hopi. American Anthropologist Io8(I):I48-I62.

Combahee River Collective

I977 A Black Feminist Statement. In Capitalist Patriarchy and the Case for Socialist Feminism, edited by Zillah Eisenstein, pp. 210-2I8. Monthly Review Press, New York. 
Constan, Connie

20I I Ceramic Resource Selection and Social Violence in the Gallina Area of the American Southwest. Unpublished PhD Dissertation, University of New Mexico, Albuquerque.

Constan, Connie I and Bremer, J. Michael

2017 From Discovery to Explanation: The History of Gallina Archaeology. Kiva 83(4):450-470.

Cope, Edward

I 879 Report on the Remains of Population Observed in Northwestern New Mexico. In Annual Report Upon the Geographical Explorations and Surveys West of the One Hundredth Meridian, In California, Nevada, Nebraska, Utah, Arizona, Colorado, New Mexico, Wyoming, and Montana, edited by George M. Wheeler, pp. 35I-36r. Appendix LL of the Annual Report of the Chief of Engineers for 1875 , Government Printing Office, Washington.

Cushing, Frank Hamilton

I 886 A Study of Pueblo Pottery as Illustrative of Zuni Culture Growth. In Bureau of American Ethnology, Fourth Annual Report, 1882-83, pp. 467-521. Smithsonian Institution Press, Washington, DC.

Dick, Herbert W.

I976 Archaeological Excavations in the Llaves Area, Santa Fe National Forest, New Mexico, 1972-1974.

Pt. I: Architecture. Archeological Report I3. Manuscript on file at USDA Forest Service, Southwestern Regional Office, Santa Fe.

I980 Cohesive and Dispersive Configurations in Settlement Patterns of the Northern Anasazi: A Hypothesis. In Collected Papers in Honor of Helen Greene Blumenschein, edited by Albert H. Schroeder, pp. 57-82. Papers of the Archaeological Society of New Mexico Vol. 5. Archaeological Society Press, Albuquerque.

Douglass, William Boone

I9I7 The Shrines of the Small House People. El Palacio IV(3):I9-29.

Eddy, Frank W.

I966 Prehistory of the Navajo Reservoir District, Northwestern New Mexico. Museum of New Mexico, Santa Fe.

I974 Population Dislocation in the Navajo Reservoir District, New Mexico and Colorado. American Antiquity 39(I):75-84.

I977 Archaeological Investigations at Chimney Rock Mesa, 1970-1972. Memoirs of the Colorado Archaeological Society Number I, Colorado Archaeological Society, Boulder.

Ellis, Florence Hawley

I976 Report on Excavations and Studies at Rattlesnake Point. Manuscript on file at the Santa Fe National Forest, Santa Fe.

I988 From Drought to Drought: Gallina Culture Patterns: Canjilon Mountain Hunting and Gathering Sites, Vol. 1. Sunstone Press, Santa Fe.

I99I A Gallina Kiva? In Puebloan Past and Present: Papers in Honor of Stewart Peckham, edited by Meliha S. Duran and David T. Kirkpatrick, pp. 7I-73. Archaeological Society of New Mexico, Albuquerque.

Elyea, Janette (editor).

I994 The Jones Canyon Survey. UNM-OCA Report No. I85-489, Office of Contract Archaeology, University of New Mexico, Albuquerque.

Emerson, Thomas E., and Timothy R. Pauketat

2002 Embodying Power and Resistance at Cahokia. In Dynamics of Power, edited by Maria O'Donovan, pp. I05-I25. Southern Illinois University Press, Carbondale.

Fiero, Kathleen

I978 Archaeological Investigation at LA I I 850: A Gallina Phase Village on the Continental Divide, Rio Arriba County, New Mexico (Review Draft). Laboratory of Anthropology Notes No. IIIf. Museum of New Mexico, Santa Fe, NM. 
Ford, Richard I., Albert H. Scroeder, and Stewart L. Peckham

I972 Three Perspectives on Puebloan Prehistory. In New Perspectives on the Pueblos, edited by Alfonso Ortiz, pp. 22-40. University of New Mexico Press, Albuquerque.

Foucault, Michel

1978 The History of Sexuality: An Introduction. Translated by Robert Hurley. Vintage Books, New York.

Fowles, Severin

2008 Steps Toward an Archaeology of Taboo. In Religion, Archaeology, and the Material World, edited by Lars Fogelin, pp. I 5-37. Center for Archaeological Investigations, Carbondale.

2010 People Without Things. In An Anthropology of Absence: Materializations of Transcendence and Loss, edited by Mikkel Bille, Frida Hastrup, and Flohr Tim Soerensen, pp. 23-4I. Springer, New York, NY.

Franks, Benjamin

20I4 Anti-Fascism and Prefigurative Ethics. Affinities: A Journal of Radical Theory, Culture, and Action 8 (I):44-72.

Glowacki, Donna M.

2015 Living and Leaving: A Social History of Regional Depopulation in Thirteenth-Century Mesa Verde. University of Arizona Press, Tucson.

Green, Roger C.

I956 A Pit House of the Gallina Phase. American Antiquity XXII(2):I88-I93.

I962 The Hormigas Site of the Largo-Gallina Phase. El Palacio 69(3):142-I 57.

I964 The Carricito Community. El Palacio 7I(2):27-39.

Green, Roger C., Maryanne A. Danfelser, and Gwinn Vivian

I958 Interpretation of Bg 9I: A Specialized Largo-Gallina Surface Structure. El Palacio 65(2):4I-60.

Guernsey, Samuel J., and Alfred V. Kidder

I92I Basket Maker Caves of Northeastern Arizona: Report on the Explorations, 1916-1917. Papers of the Peabody Museum of American Archaeology and Ethnology. Harvard University, Cambridge.

Halbwachs, Maurice

I992 On Collective Memory. Harper \& Row, New York.

Hall, Edward Twitchell

I944 Early Stockaded Settlements in the Governador, New Mexico: A Marginal Anasazi Development from Basket Maker Times to Pueblo I Times. Columbia Studies in Archaeology and Ethnology. Columbia University Press, New York.

Harry, Karen G., and Sarah A. Herr (editors).

20I8 Life Beyond the Boundaries: Constructing Identity in Edge Regions of the North American Southwest. University Press of Colorado, Boulder.

Hayden, John S.

1978 Site No. GBW-6: Progress Report, The First and Second Season, 1977 and 1978. Report on file. Florence Hawley Ellis Archives.

Hays-Gilpin, Kelley, and Jane H. Hill

I999 The Flower World in Material Culture: An Iconographic Complex in the Southwest and Mesoamerica. Journal of Anthropological Research 55(I):I-37.

Helton-Croll, Claire K.

20I0 Why Conical Pots? An Examination of the Relationship Among Vessel Shape, Subsistence, and Mobility. Unpublished PhD Dissertation, University of New Mexico, Albuquerque.

Hibben, Frank C.

1938 The Gallina Phase. American Antiquity 4(2):I3 I-I36.

I939 The Gallina Culture of North Central New Mexico. Unpublished PhD Dissertation, Harvard University, Cambridge.

I948 The Gallina Architectural Form. American Antiquity I4(I):32-36.

I949 The Pottery of the Gallina Complex. American Antiquity I4(3):I94-202. 
Hicks, Frederic

I949 A Gallina Unit House of Northwestern New Mexico. Unpublished Manuscript on file, University of New Mexico, Albuquerque.

Hobsbawm, Eric

I992 Introduction: Inventing Traditions. In The Invention of Tradition, edited by Eric J. Hobsbawm and Terence O. Ranger, pp. I-I4. Cambridge University Press, Cambridge.

Holbrook, Sally J., and James C. Mackey

I976 Prehistoric Environmental Change in Northern New Mexico: Evidence from a Gallina Phase Archaeological Site. Kiva 4I(3/4):309-3I7.

Jeancon, Jean Allard

1922 Archaeological Research in the Northeastern San Juan Basin of Colorado During the Summer of 1921. Historical Society of Colorado and the University of Denver, Denver.

Jenkins, Richard

2004 Social Identity. Routledge, London.

Jennings, Jesse D., Erik K. Reed, James B. Griffin, J. Charles Kelley, Clement W. Meighan, Stanley Stubbs, Joe Keeley, Lawrence H.

I996 War Before Civilization. Oxford University Press, Oxford.

Kidder, Alfred Vincent

I924 An Introduction to the Study of Southwestern Archaeology with a Preliminary Account of the Excavations at Pecos. Yale University Press, New Haven.

Kliendienst, Maxine

I956 Gallina Phase Cliffhouses: A Report on Excavations in Northcentral New Mexico in 1954-55. Unpublished Master's Thesis, University of Chicago, Chicago.

Knight, Terry L.

1990 Largo Gallina Ceramics: Inter/Intra Site Variability in Cultural and Technological Attributes. Paper presented at the $55^{\text {th }}$ Annual Meeting of the Society for American Archaeology, Las Vegas, Nevada.

Kocer, Jacqueline

2014 An Examination of Gallina Utility Ware: Vessel Morphology and Function. Unpublished Master's Thesis, Anthropology Department, University of New Mexico, Albuquerque.

Kocer, Jacque Marie and Jeffrey Ferguson

2017 Investigating Projectile Point Raw Material Choices and Stylistic Variability in the Gallina Area of Northwestern New Mexico. Kiva 83(4):532-554.

Koehring, Vera

I948 An Analysis of Gallina Painted Pottery Design. Unpublished Manuscript on file, University of New Mexico, Albuquerque.

Kohler, Timothy A., Scott G. Ortman, Katie E. Grundtisch, Carly M. Fitzpatrick, and Sarah M. Cole

2014 The Better Angels of Their Nature: Declining Violence Through Time Among Prehispanic Farmers of the Pueblo Southwest. American Antiquity 79(3):444-464.

Kuckelman, Kristin A., and Debra L. Martin

20I2 Taphonomy and Warfare in the Mesa Verde Region. Landscapes of Violence 2(2):Article I3. http:// scholarworks.umass.edu/lov/vol2/iss2/.

Lange, Charles $\mathrm{H}$.

I94 I The Evans Site: A Contribution to the Archaeology of the Gallina Region, Northern New Mexico. Unpublished Master's Thesis, University of New Mexico, Albuquerque.

I956 The Evans Site and the Archaeology of the Gallina Region, New Mexico. El Palacio 63:72-92.

Lekson, Stephen H. (editor).

2006 The Archaeology of Chaco Canyon: An Eleventh-Century Pueblo Regional Center. SAR Press, Santa Fe. Lewis, James R., and Olav Hammer

2007 Introduction. In The Invention of Sacred Tradition, edited by James R. Lewis and Olav Hammer, pp. I-I7. Cambridge University Press, Cambridge. 
Lowenthal, David

I98 5 The Past Is a Foreign Country. Cambridge University Press, Cambridge.

Mackey, James C.

I977 A Multivariate, Osteological Approach to Towa Culture History. American Journal of Physical Anthropology 46(3):477-482.

I982 Vallecitos Pueblo (A Fourteenth Century A.D. Ancestral Jemez Site), and LA I276I (A Late Prehistoric - Early Historic, Jemez Phase Farm House Site) in New Mexico. Journal of Intermountain Archeology I(2):80-99.

Mackey, James C., and Roger C. Green

I979 Largo-Gallina Towers: An Explanation. American Antiquity 44(I):I44-I 54.

Mackey, James C., and Sally J. Holbrook

I975 Archeological Report Submitted to Santa Fe National Forest for Work done in 1973-1974 Under Forest Service Permit on Federal Lands in the Cuba and Coyote Districts. Manuscript on file at the Laboratory of Anthropology, Santa Fe, NM.

Malville, J. McKim (editor)

2004 Chimney Rock: The Ultimate Outlier. Lexington Books, Boulder.

Matlock, Gary M., and J. McKim Malville (editors)

I993 The Chimney Rock Archaeological Symposium: October 20-21, 1990: Durango, Colorado. USDA Forest Service General Technical Report RM-227, Rocky Mountain Forest and Range Experiment Station, U.S. Department of Agriculture, Fort Collins.

Maxwell, Dan, Dyan Mazurana, Michael Wagner, and Rachel Slater

2017 Livelihoods, Conflict and Recovery: Findings from the Secure Livelihoods Research Consortium. Secure Livelihoods Research Consortium, London.

McGregor, John C.

I94I Southwestern Archaeology. John Wiley, Hoboken.

Mera, Harry P.

I935 Ceramic Clues to the Prehistory of North Central New Mexico. Laboratory of Anthropology, Santa Fe.

Mills, Barbara J.

I985 "North American Cooking Pots" Reconsidered: Some Behavioral Correlates of Variation in Cooking Pot Morphology. Paper presented at the 5oth Annual Meeting of the Society for American Archaeology, Denver, Colorado.

Myers, Nate

2007 A Typological Assessment of the Mesa Portales Ceramics. Unpublished Master's Thesis, Eastern New Mexico University, Portales.

O’Donnell, Alexis, and Corey S. Ragsdale

20 I 7 Biological distance analysis and the fate of the Gallina in the American Southwest. Kiva 83(4):5 I 5-53 I.

Ortiz, A.

I969 The Tewa World: Space, Time, Being, and Becoming in a Pueblo Society. University of Chicago Press, Chicago.

Ortman, Scott G.

$20 \mathrm{I} 2$ Winds from the North: Tewa Origins and Historical Anthropology. University of Utah Press, Salt Lake City.

Pattison, Natalie B.

I968 Nogales Cliff House: A Largo Gallina Site. Unpublished Master's Thesis, University of New Mexico, Albuquerque.

Peeples, Matthew A.

2018 Connected Communities: Social Networks, Identity, and Social Change in the Ancient Cibola Word. The University of Arizona Press, Tucson.

Pierce, Christopher

2005 The Development of Corrugated Pottery in Southwestern Colorado. Kiva 7I(I):79-I00. 
Potter, James M., and Jason P. Chuipka

20I0 Perimortem Mutilation of Human Remains in an Early Village in the American Southwest: A Case for Ethnic Violence. Journal of Anthropological Archaeology 29(4):507-523.

Potter, James M., Jason P. Chuipka, and Jerry Fetterman

2012 The Eastern Mesa Verde Region: Migrants, Cultural Diversity, and Violence in the East. In Crucible of Pueblos: The Early Pueblo Period in the Northern Southwest, edited by Richard H. Wilshusen, Gregson Schachner, and James R. Allison, pp. I4-34. Cotsen Institute of Archaeology Press, Los Angeles.

Reed, Lori S., and Joell Goff

2007 A Field Guide to Upper San Juan Anasazi and Navajo Pottery. Prepared for NMAC Ceramic Workshop, Farmington, New Mexico.

Reiter, Paul

1938 The Jemez Pueblo of Unshagi, New Mexico, with Notes on the Earlier Excavations at "Amoxiumqua" and Giusewa. In Monographs of the School of American Research, 5-6. University of New Mexico Press, Albuquerque.

Roberts, Frank H.H.,

I930 Early Pueblo Ruins in the Piedra District, Southwestern Colorado. Bulletin No. 96. Bureau of American Ethnology, Washington, DC.

Sassaman, Kenneth E.

$200 \mathrm{I}$ Hunter-Gatherers and Traditions of Resistance. In The Archaeology of Traditions: Agency and History Before and After Columbus, edited by Timothy R. Pauketat, pp. 218-236. University Press of Florida, Gainesville.

Schulman, Albert

I950 Pre-Columbian Towers in the Southwest. American Antiquity I 5(4):288-297.

Shannon, Deric, and J. Rogue

20I4 Refusing to Wait. Zabalaza, Johannesburg.

Simpson, Erik

2008 Architectural Patterning in Residential Structures in the Gallina Area. Unpublished Master's Thesis, Prescott College, Prescott.

2016 Modeling Post A.D. 700 Population Movements and Culture in the Upper San Juan Region. In Exploring Cause and Explanation: Historical Ecology, Demography, and Movement in the American Southwest, edited by Cynthia L. Herhahn and Ann F. Ramenofsky, pp. 257-274. University Press of Colorado, Boulder.

Sleeter, Richard Stanley

I987 Cultural Interaction of the Prehistoric Gallina: A Study of Settlement Patterns in North-Central New Mexico. Unpublished Master's Thesis, New Mexico State University, Las Cruces.

Snow, Bryan Edward

I978 Owl Point: A Largo-Gallina Site in Billy Rice Canyon, New Mexico. Unpublished Master's Thesis, University of Toronto, Toronto.

Stark, Miriam T., Mark D. Elson, and Jeffrey J. Clark

I998 Social Boundaries and Technical Choices in Tonto Basin Prehistory. In The Archaeology of Social Boundaries, edited by Miriam T. Stark, pp. 208-23I. Smithsonian Institution Press, Washington, DC.

Steen, Carl

I999 Pottery, Intercolonial Trade, and Revolution: Domestic Earthenwares and the Development of an American Social Identity. Historical Archaeology 33(3):62-72.

Stodder, Ann Lucy Wiener

I989 Bioarchaeological Research in the Basin and Range Region. In Human Adaptations and Cultural Change in the Greater Southwest: An Overview of Archeological Resources in the Basin and Range Province, edited by Alan H. Simmons, Ann Lucy Wiener Stodder, Douglas D. Dykeman, and Patricia A. Hicks, pp. I67-I90. Final Report Submitted to the U.S. Army Corps of Engineers, Southwestern Division. Study Unit 4 of the Southwestern Division Archeological Overview. 
Stuart, David E., and Robin E. Farwell

${ }_{1983}$ Out of Phase: Late Pithouse Occupations in the Highlands of New Mexico. In High-Altitude Adaptations in the Southwest, edited by Joseph C. Winter, pp. II4-I58. Cultural Resources Management Report No. 2. United States Department of Agriculture, Forest Service, Southwestern Region, Albuquerque.

Stuart, David E., and Rory P. Gauthier

I98I Prehistoric New Mexico: Background for Survey. Historic Preservation Bureau, Santa Fe.

Sutherland, Edwin H.

I945 Social Pathology. American Journal of Sociology 50(6):429-435.

Todd, Brenda K.

$20 \mathrm{I} 2$ Chimney Rock, an Eleventh Century Chacoan Great House: Export, Emulation, or Something Else? Unpublished PhD Dissertation, University of Colorado, Boulder.

Tonkinson, Robert

2000 "Tradition" in Oceania, and Its Relevance in a Fourth World Context (Australia). Folk 42:I69-95.

Trigger, Bruce G.

2008 A History of Archaeological Thought. 2nd ed. Cambridge University Press, Cambridge.

Turner, Christy G., Jacqueline A. Turner, and Roger C. Green

I993 Taphonomic Analysis of Anasazi Skeletal Remains from Largo-Gallina Sites in Northwestern New Mexico. Journal of Anthropological Research 49(2):83-I IO.

Wallace, Anthony F.C.

I956 Revitalization Movements. American Anthropologist 58(2):264-28I.

Weik, T. M.

2014 The Archaeology of Ethnogenesis. Annual Review of Anthropology 43(I):29I-305.

Wilcox, David R., and Jonathan Haas

I994 The Scream of the Butterfly: Competition and Conflict in the Prehistoric Southwest. In Themes in Southwest Prehistory, edited by George J. Gumerman, 2II-238. School of American Research Press, Santa Fe.

Wills, Wirt H., F. Scott Worman, Wetherbee Dorshow, and Heather Richards-Rissetto

2012 Shabik'eschee Village in Chaco Canyon: Beyond the Archetype. American Antiquity 77(2):326-350. Wilshusen, Richard H., Scott G. Ortman, Shanna R. Diederichs, Donna M. Glowacki, and Grant Coffey 2012 Heartland of the Early Pueblos: The Central Mesa Verde. In Crucible of Pueblos: The Early Pueblo Period in the Northern Southwest, edited by Richard H. Wilshusen, Gregson Schachner, and James R. Allison, pp. I4-34. Cotsen Institute of Archaeology Press, Los Angeles.

Wilshusen, Richard H., and Ruth M. Van Dyke

2006 Chaco's Beginnings: The Collapse of Pueblo I Villages and the Origins of the Chaco System. In The Archaeology of Chaco Canyon, An Eleventh Century Pueblo Regional Center, edited by Stephen H. Lekson, pp. 2I I-259. SAR Press, Santa Fe.

Wilson, C. Dean

I994 Ceramic Analysis. In The Jones Canyon Survey, edited by Janette Elyea. UNM-OCA Report No. I 85-489, Office of Contract Archaeology, University of New Mexico, Albuquerque.

Windes, Thomas C., and Ruth M. Van Dyke

2012 Pueblo I Settlement in the Greater Chaco Basin. In Crucible of Pueblos: The Early Pueblo Period in the Northern Southwest, edited by Richard H. Wilshusen, Gregson Schachner, and James R. Allison, pp. 72-IOo. Cotsen Institute of Archaeology Press, Los Angeles.

Wiseman, Regge N.

2007 On the Relationship Between the Largo-Gallina and the Jemez. In Texas and Points West: Papers in Honor of John A. Hedrick and Carl P. Hedrick, edited by Regge N. Wiseman, Thomas C. O'Laughlin, Cordelia T. Snow, and Cathy Travis, pp. 20I-222. Papers of the Archaeological Society of New Mexico, Albuquerque. 